УДК 811.111'33:821.111

DOI https://doi.org/10.52726/as.humanities/2021.3.23

\author{
Н. Й. ЧЕТОВА \\ кандидат філологічних наук, доцент, \\ дочент кафедри іноземних мов, \\ Національний університет «Львівська політехніка», м. Львів, Украӥна \\ Електронна пошта: kern_nata@ukr.net \\ https://orcid.org/0000-0003-3075-1692
}

\title{
ЛІНГВОКОГНІТИВНЕ УТІЛЕННЯ ПРИВИДУ В АНГЛОМОВНІЙ ЛІТЕРАТУРІ ПРО НАДПРИРОДНЕ (НА МАТЕРІАЛІ ЖАНРІВ ІСТОРІЯ ПРО ПРИВИДІВ, ГОТИЧНИЙ РОМАН ТА ФЕНТЕЗІ)
}

У статті представлено дослідження привидів в англійській літературі про надприродне. У процесі наукової розвідки проаналізовано реалізації особливостей примар на мовному та когнітивному рівнях в англійських літературних творах таких жанрів, як історія про привидів, готичний роман та фентезі. У процесі дослідження увага зосереджена на аналізі номінативного аспекту вербалізації привидів, зокрема лексико-семантичному просторі, поряд із структуруванням основної інформації, отриманої в результаті аналізу контекстів, де згадувалися привиди, та представленої як каркас змістового шару художнього концепту ПРИВИД. Методологією дослідження передбачено застосування комплексного підходу, який базується на лінгвопоетичному та концептуальному аналізі. Мовні аспекти втілення різноманітних характеристик привидів вивчено в літературній творчості Ч. Діккенса, О. Вайлда, Дж. Р. Р. Толкіна і Дж. К. Роулінг, де найяскравіше реалізується категорія уявного, виражена цими примарами, і де вона є жанротвірною ознакою.

На основі системно-функціонального та семантичного аналізу можливо диференціювати та групувати слова, що вербалізують розмаїття привидів в аналізованих літературних творах. Логічно структурована інформація про цих істот розкриває основну ментальну презентацію явища, його компонентів, взаємодія яких представлена у вигляді фрейму, та демонструє знання про привидів, накопичені в англійській літературі.

Дослідження висвітлює феномен привиду як вияв надприродного та як один із найяскравіших прикладів реалізації категорії уявного в літературі та розкриває його спільні риси в художній літературі, зокрема в англомовних творах таких жанрів, як історія про привидів, готичний роман та фентезі.

Ключові слова: привид, фентезі, історія про привидів, готичний роман, художній концепт, змістовий шар, фрейм.

Постановка проблеми. Надзвичайною популярністю останнім часом користується художня література казково-фантастичного характеру, зокрема про надприродне, що уможливлює втечу читача від недосконалої буденності у світ фантазій, де нереальне стає можливим, де на кожному кроці дива, де Добро неодмінно здолає Зло, а справедливість завжди перемагає. 3 огляду на це, дослідження художніх творів, у яких найяскравіше висвітлено різні грані надприродного, що провокує цікавість читача, $є$ доречним та актуальним, оскільки сприяє розкриттю причин такого інтересу численних шанувальників. Аналіз надприродного на прикладі одного з його виявів із точки зору лінгвокогнітивної реалізації забезпечує висвітлення своєрідності ментального конструювання та вербального втілення складників тієї уявної дійсності, яка так приваблює любителів історій про привидів, готичних романів та фентезі.
Аналіз попередніх досліджень. Серед дослідників, які вивчали різні аспекти своєрідності літератури про надприродне, слід відмітити таких мовознавців, як Г. Айденіз, І. Александрук, Н. Алєфірєнко, О. Божко, Н. Болотнова, С. Васильєв, Н. Вільсон, Г. Волчанська, О. Галич, О. Головко, Н. Сремеєва, Л. Жогіна, Г. Кавальєро, В Кадуріна, Є. Канчура, О. Колесник, Е. Дж. Клері, Д. Куриленко, Г. Ф. Лавкрафт, Л. Мацапура, Д. Павкін, В. Пропп, П. Рікьор, Н. Ситник, Т. Тодоров та ін. Їх наукові напрацювання містять дослідження специфіки надприродного, його ролі у творенні вигаданої реальності, його лінгвокогнітивного втілення.

Мета статті - з'ясувати особливості лінгвальної актуалізації явища ПРИВИД для реконструкції іiі когнітивної організації в англомовній літературі $з$ елементами про надприродне у творах таких жанрів, як історія про привидів, готичний роман та фентезі. Для цього необ- 
хідно дати визначення феномену ПРИВИД у художній літературі, слід виокремити мовний арсенал на позначення аналізованого поняття (прямі та непрямі засоби номінації) в контекстах його актуалізації та змоделювати фрейм змістового шару художнього концепту (далі ХК) ПРИВИД, який надає уніфіковану інформацію про складники досліджуваного явища в розглянутих творах, що у схематичній формі репрезентує уявлення англійців про привидів, що реалізувалось у найяскравіших творах жанрів, пов'язаних із категорією надприродного.

Предметом розгляду $є$ лексичні одиниці (далі - ЛО), які вербалізують феномен ПРИВИД в англомовних історіях про привидів, готичному романі та фентезі. Об'єктом аналізу $\epsilon$ їх семантичні особливості як такі, через які реалізується когнітивний рівень актуалізації цього явища. Матеріалом наукової розвідки слугують англомовні художні твори таких жанрів, як історія про привидів (“A Christmas Carol” (1843) Ч. Діккенса), готичний роман ("The Canterville Ghost" (1887) та "The Picture of Dorian Gray" (1891) О. Вайлда) та фентезі ("Hobbit" (1937), "The Lord of the Rings" (1954-1955) Дж. Р. Р. Толкіна та "Harry Potter and the Chamber of Secrets" (1998), "Harry Potter and Half-Blood Prince" (2005) Дж. К. Роулінг), відібрані на основі наявності в них надприродного, зокрема уявних неживих суб'єктів.

Виклад основного матеріалу. Згідно з Академічним тлумачним словником української мови привид - дещо, що привиділось, ілюзія або плід фантазії. У фольклорі, фентезі та жахах привид - душа людини, що з якоїсь причини не пішла в потойбічний світ, через прокляття або невиконані за життя справи [АТСУМ : ел. рес.]. За віруваннями багатьох народів, після смерті людини в матеріальному світі залишається іiі нематеріальна частина - душа, вияв якої у світі живих зветься привидом і виникає у разі неприродної смерті, недотримання ритуалу поховання чи сторонніх вчинків, які не відпускають душу у світ мертвих. Класичний образ привиду - це біла, нечітка, напівпрозора форма тіла людини, тварини чи предмета.

В англомовній довідковій літературі знаходимо такі тлумачення слова ghost, як: "the spirit of a dead person that a living person believes they can see or hear" [Oxford Learners Dictionary : el. ref.] та "the soul of a dead person, a disembodied spirit imagined, usually as a vague, shadowy or evanescent form, as wandering among or haunting living persons; a mere shadow or semblance; a trace". [Dictionary.com : el. ref.]. Lexico.com визначає ghost як "an apparition of a dead person which is believed to appear to the living, typically as a nebulous image" [Lexico.com : el. ref.].

Енциклопедія Britannica надає таке тлумачення: "ghost, soul or spectre of a dead person, usually believed to inhabit the netherworld and to be capable of returning in some form to the world of the living. According to descriptions [...] provided by believers, a ghost may appear as a living being or as a nebulous likeness of the deceased or, occasionally, in other forms. Belief in ghosts is based on the ancient notion that a human spirit is separable from the body and may maintain its existence after the body's death. In many societies, funeral rituals are believed to prevent the ghost from haunting the living" [Britannica.com : el. ref.]

Серед синонімів слова ghost, за допомогою яких досліджуване явище може утілюватися в художніх текстах, ціла палітра варіантів вербалізації: demon, devil, phantom, shadow, soul, spectre, vampire, vision, apparition, appearance, banshee, daemon, haunt, kelpie, manes, phantasm, poltergeist, revenant, shade, spook, visitor, wraith, zombie, eidolon, ethereal being, incorporeal being [Thesaurus.com : el. ref.].

Visual Thesaurus надає таке візуальне представлення змісту слова ghost та його синонімів (див. рис. 1) [Visual Thesaurus : el. ref.]:

Далі розглянемо, як досліджуване явище реалізується в художніх творах різних письменників, пов'язаних спільною ознакою - література 3 елементами про надприродне - Ч. Діккенса, О. Вайлда, Дж. Р. Р. Толкіна та Дж. К. Роулінг, на яких його характерних рисах автори акцентують увагу читачів. Так, у творах зазначених авторів привид актуалізовано такими ЛО: ghost (у всіх чотирьох авторів трапляється використання цієї ЛО (4/4)), phantom (3/4), shadow $(3 / 4)$, apparition $(2 / 4)$, shade $(2 / 4)$, spectre $(2 / 4)$, spirit (2/4), astral body (1/4), dead (body) (1/4), dream (1/4), illusion (1/4), poltergeist $(1 / 4)$, soul $(1 / 4)$, vision (1/4), wight (1/4), wraith (1/4). Зважаючи на таку статистику, для найменування аналізованого надалі ХК обрано ЛО ghost, яка превалює як якісно, так і кількісно. 
Аналіз контекстів на предмет експлікації уявних (не)живих істот уможливило ідентифікацію ХК ПРИВИД, мовна реалізація якого представлена цілою палітрою номінацій, серед яких:

1. іменникові:

а. прямі - ghost, spirit, phantom, poltergeist, wraith, shade, shadow, wight, vision, spectre, dead, apparition, astral body, dream, illusion, soul, та

b. непрямі - Inferius, Headless Nick, headless horseman, Ringwraith, Barrow-wight, Black Rider, Servant, Fat Friar та ін.

2. прикметникові: dead, transparent, terrible, black, fantastic, misshapen, white-robed, grotesque, horrible, motionless, wicked, fearful, old, misty, demoniac, furious, phosphorescent, astral, cold, vanishing, awful, brave, grisly, weak, tired, phantasmic, supernatural, shadowy, strange, infernal, faded, dreadful, condemned, doomed, stony, fiery, dark, cheerful, ragged, gaunt, glum, ancient, shriveled, reanimated, mean, castle, barely visible, shimmering insubstantially.

3. дієслівні: to separate, to flit, to sweep, to fancy, to creep, to crawl, to crouch, to bear a burden, to stretch, to judge, to flee, to utter (hollow groan), to turn into, to emit (light), to vanish, to appear, to glare (in fury), to frighten, to gibber, to walk (up and down), to raise (a cry), to wander (through the world), to interfere, to fade (into mist), to trouble, to be condemned, to shake (the chains), to be doomed, to drink (blood), to float, to reanimate, to shimmer і т.д.

Нижче подані контексти яскраво ілюструють певні особливі риси зовнішності і характеру (не)живих істот, їх діяльності та атмосфери, за якої вони функціонують чи яку створюють, та слугують ідентифікації ХК ПРИВИД.
Так, у творах Ч. Діккенса, зокрема в «Різдвяній пісні в прозі, або різдвяному оповіданні 3 привидами» примари змальовано як страхітливі істоти: There was something very awful, too, in the spectre's being provided with an infernal atmosphere of its own. [CC : 20], які після смерті 3 певних причин приречені блукати поміж людей: [...] and if that spirit goes not forth in life, it is condemned to do so after death. It is doomed to wander through the world. [CC : 21]; як привиди, які лякають довколишніх своїм воланнями, що проймають до кісток: [...] for the spectre's voice disturbed the very marrow in his bones. [CC : 20], брязканням ланцюгами й кайданками: Again the spectre raised a cry, and shook its chain and wrung its shadowy hands. [CC : 22], які вони заробили за життя і зараз змушені носити в якості покарання: 'I wear the chain I forged in life, 'replied the Ghost. [CC : 22]. Ïх присутність створює гнітючу атмосферу: The air was filled with phantoms, wandering hither and thither in restless haste, and moaning as they went. Every one of them wore chains like Marley's Ghost; some few [...] were linked together; none were free. [CC:26], а містична поява чи зникнення: Whether these creatures faded into mist, or mist en-shrouded them, he could not tell. But they and their spirit voices faded together; and the night became as it had been when he walked home. [CC : 26] приносить полегшення та повертає звичний стан / хід речей. Особливим для примар Діккенса є те, що прямо або опосередковано зустрічається інформація про їх професію чи посаду: He had been quite familiar with one old ghost, in a white waistcoat, with a monstrous iron safe attached to its ankle. [CC : 26], а також 'Who were you then?'

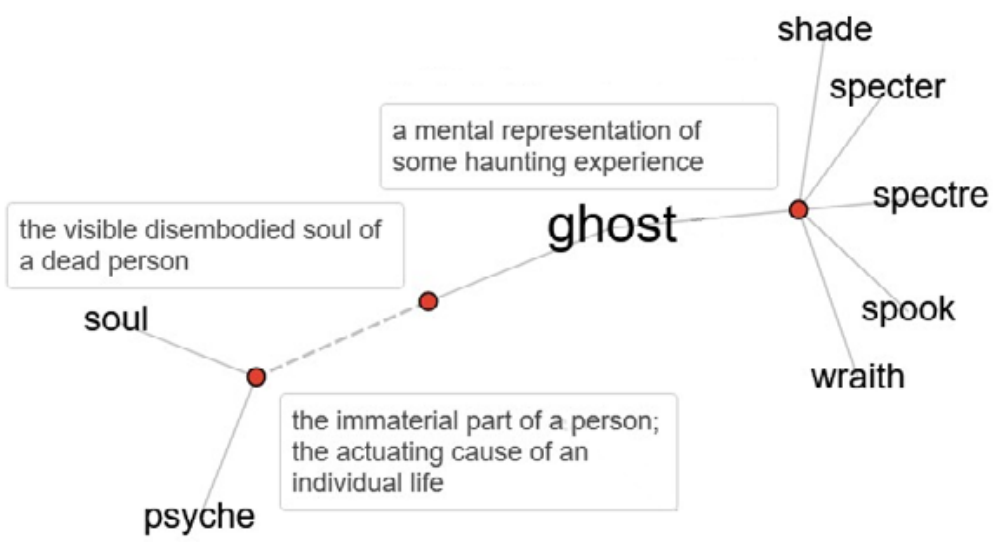

Рис. 1. Візуальне представлення синонімів до слова ghost 
said Scrooge, raising his voice. 'You're particular, for a shade.' He was going to say 'to a shade, but substituted this, as more appropriate. 'In life I was your partner, Jacob Marley.' [CC : 19], де привид стверджує, що він Джейкоб Марлі і за життя був діловим партнером головного персонажа твору - скнари-лихваря Ебенезера Скруджа, тому, вочевидь, після смерті через свою байдужість до нужденних людей як покути змушений бродити світом, закутий у ланцюги, 3 касами й книгами бухгалтерського обліку, що яскраво ілюструє реалізацію професійної приналежності примари.

У «Кентервільському привиді» О. Вайлда теж знаходимо інформацію про те, що привиди характерні для громадських місць типу музеїв чи яких-небудь шляхів: [...] I reckon that if there were such a thing as a ghost in Europe, we'd have it at home in a very short time in one of our public museums, or on the road as a show. [CG : 1], 3'являються за певних містичних обставин: The second appearance of the ghost was on Sunday night. Shortly after they had gone to bed they were suddenly alarmed by a fearful crash in the hall [CG : 5], лякаючи свідків як своїм зовнішнім виглядом, так і лютим, демонічним крикомсміхом аж до появи сивини: The ghost started up with a wild shriek of rage, and swept through them like a mist, extinguishing Washington Otis's candle as he passed, and so leaving them all in total darkness. On reaching the top of the staircase he recovered himself and determined to give his celebrated peal of demoniac laughter. [...] It was said to have turned Lord Raker's wig grey in a single night, [...]. He accordingly laughed his most horrible laugh, till the old vaulted roof rang and rang again, but hardly had the fearful echo died away [...]. [CG : 6]. Крім того, письменник акцентує увагу читача на не менш вражаючій здатності привидів набувати різних подоб: The ghost glared at her in fury, and began at once to make preparations for turning himself into a large black dog, [...]. The sound of approaching footsteps, however, made him hesitate in his fell purpose, so he contented himself with becoming faintly phosphorescent, and vanished with a deep church-yard groan. [ibid.] та навіть певної метаморфічної форми космічного / просторового виміру: For a moment the Canterville ghost stood quite motionless in natural indignation; then, [...] he fled down the corridor, uttering hollow groans, and emitting a ghastly green light. [...] so, hastily adopting the Fourth Dimension of Space as a means of escape, he vanished through the wainscoting, and the house became quite quiet [CG : 4] чи астрального тіла: The question of phantasmic apparitions, and the development of astral bodies, was of course quite a different matter, and really not under his control [CG : 8].

В іншому своєму творі - «Портрет Доріана Грея» - О. Вайлд розкриває дещо інші аспекти цього явища. Так, у контексті Black fantastic shadows crawl into the corners of the room, and crouch there [PDG : 166] примари змальовано як уявних істот, які, ймовірно, навіть не людино- чи твариноподібні, а у реченні Was the soul a shadow seated in the house of sin? Or was the body really in the soul, as Giordano Bruno thought? The separation of spirit from matter was a mystery, and the union of spirit with matter was a mystery also [PDG : 72] автор розмірковує про природу трансформації людської душі через гріх у привид та про той гріховний тягар як атрибут, який ця істота часом несе не з власної волі, а як покуту за справжнього винуватця: $O n$ his return he would sit in front of the picture [...] smiling, with secret pleasure, at the misshapen shadow that had to bear the burden that should have been his own. [PDG : 179-180]. Хоча це химерне створіння насправді є утіленням душі грішника-злочинця: His own soul was looking out at him from the canvas and calling him to judgment [PDG : 146], що свідчить про ще одну характерну ознаку привида - двійник або допельгангер [Clute : 284] - антитеза янголу-охоронцю, одночасна проєкція із живим героєм твору, чиєю душею до гріховного падіння він був, що сповіщає його неминучу і швидку смерть.

Твори Дж. Р. Р. Толкіна - «Гобіт» та «Володар Перснів» - також містять палітру всіляких химер, які, попри спільні з попередніми варіантами ознаки, мають і низку відмінних, наведених у таких прикладах. Так, речення Barrowwights walked in the hollow places with a clink of rings on cold fingers, and gold chains in the wind. [FR : 141] ілюструє ті ж типові риси примар брязкання ланцюгами й перснями на холодних пальцях. Проте привиди у творах Дж. Р. Р. Толкіна відрізняються тим, що постають у подобі Чорних Вершників - Примар Персня, які слу- 
гують своєму повелителю - Володарю Перснів: [...] the Black Riders are the Ringwraiths, the Nine Servants of the Lord of the Rings. [FR : 232]. Cneцифічним для Толкінових привидів є те, що деякі з них п'ють кров: The Woodmen said that there was some new terror abroad, a ghost that drank blood. [FR : 67], а також згадуються примари тварин: As Frodo watched he saw something dark pass across the lighter space between two trees, and then halt. It looked like the black shade of a horse led by a smaller black shadow. [FR : 88] та навіть привиди живих: It was an evil phantom of Saruman that we saw last night. [TT : 91]. 3a версією Дж. Р. Р. Толкіна, ці химери самі по собі знищити неможливо, а лише разом із їх повелителем: 'You cannot destroy Ringwraiths like that, [...] The power of their master is in them, and they stand or fall by him.' [FR : 286].

У творах сучасної письменниці Дж. К. Роулінг про Гаррі Поттера також немало прикладів, де розкриваються певні характеристики привидів. Так, із контексту The castle ghosts were there too, barely visible in the bright sunlight, discernible only when they moved, shimmering insubstantially on the gleaming air. [НВР : 834] отримуємо інформацію про те, як примари виглядають і що існують у замках. У реченні He could hear echoing footsteps and then a dark shadow moved in front of him. [CS : 272] бачимо притаманні привиду передвісники появи. Із контексту ситуації Unlike the ghosts around them, Peeves the Poltergeist was the very reverse of pale and transparent. He was wearing a bright orange party hat, a revolving bow tie, and a broad grin on his wide, wicked face. [CS : 114] дізнаємось як про типовий вигляд привида, так і про незвичайний - що (порівняно 3 традиційним описом таких істот попередніми авторами) є відмінною ознакою.

Подібно до Толкіна у творах Роулінг теж наявні випадки примар тварин: Through the dungeon wall burst a dozen ghost horses, each ridden by a headless horseman. [CS : 116], та аналогічно «Різдвяній пісні у прозі» у циклі про Гаррі Поттера вказано на професійну належність привида: Professor Binns, [...], was their only ghost teacher, and the most exciting thing that ever happened in his classes was his entering the room through the blackboard. Ancient and shriveled, many people said he hadn't noticed he was dead. He had simply got up to teach one day and left his body behind him in an armchair in front of the staff room fire; his routine had not varied in the slightest since. [CS : 127].

Дещо нетиповим для характеристики примар $\epsilon$ змалювання Роулінг емоційної сфери чи внутрішнього світу привидів - як от у реченні: "I wish people would stop talking behind my back!" said Myrtle, in a voice choked with tears. "I do have feelings, you know, even if I am dead-" [CS : 134], а також зазначення причин чи джерела їх появи: "The Inferius is a corpse that has been reanimated by a Dark wizard's spells. It is not alive, it is merely used like a puppet to do the wizard's bidding. A ghost, as I trust that you are all aware by now, is the imprint of a departed soul left upon the earth... and of course, as Potter so wisely tells us, transparent." [НВР : 599], де peaлізовано ще одну ознаку примари - схожу до привидів Толкіна - підпорядкування ії творцю. Крім того, на противагу створінням попередніх авторів, тільки у Роулінг знаходимо диференціацію істот на прозорі та щільні/тверді: "Yeah, ghosts are transparent, but Inferi are dead bodies, aren't they? So they'd be solid-" [HBP : 599].

Аналіз мовного утілення феномену привид в англомовних творах про надприродне з позиції прямої й непрямої номінації та контекстної реалізації, а також залучення методики лінгвокогнітивного аналізу вможливлює відтворення ХК ПРИВИД. Його реконструкція здійснена способом виокремлення набору ключових слів, що сприяють мовній актуалізації явища ПРИВИД, аналізу їх лексикографічних тлумачень i сполучуваності у контекстах та виділення ключових контекстів, визначення їх тематичних ліній та ідентифікація серед мовних засобів тематичних домінант та аналізу контекстуальних зв'язків цих домінант - смислових релятів (В. Г. Ніконова [Ніконова 2005]).

Підхід уважається вдалим, оскільки дозволяє залучити не тільки лексикографічні експлікації, а й усю глибину контекстів, які на основі інтуїтивного осмислення значно розширюють гаму потенційних значень.

Так, у реченні $\underline{A \text { vision }}$ it was that you saw, I think, and no more, some shadow of evil fortune that has been or will be [TT : 275] розкриваються певні містичні здібності: герой бачить видіння, тінь, примару з минулого чи майбутнього. Звідси, на основі наведеного і подібних кон- 


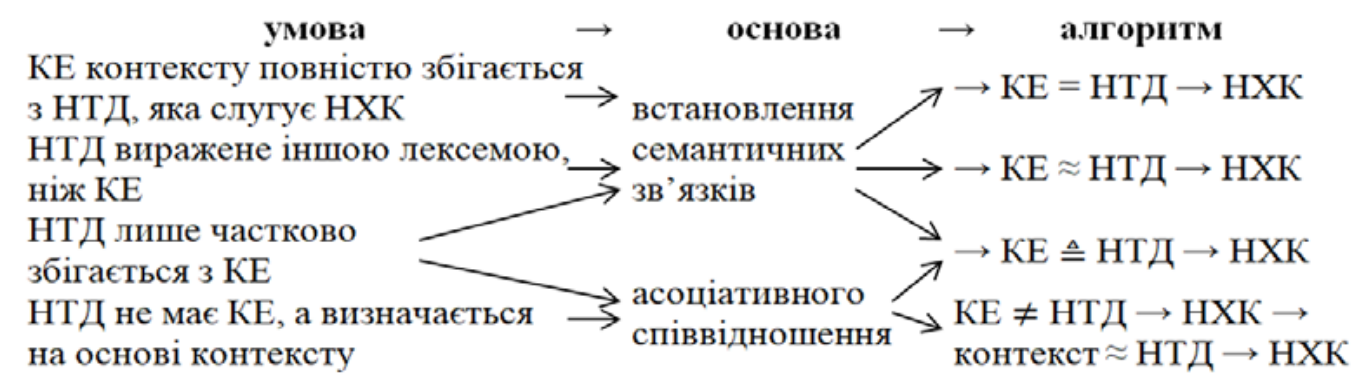

\section{Рис. 2. Способи ідентифікації художнього концепту ПРИВИД}

текстів, уважаємо за можливе виділити «ключові елементи» [Араратян : 18] контекстів, де фігурують привиди. Різноманіття таких контекстів і мовних засобів свідчать про намагання письменників викликати у свідомості читача якомога більше різнорідних виявів примари i, отже, розкрити зміст кожного її складника, сформувати чітку, логічно впорядковану картину взаємодії всіх конституентів, які у своїй сукупності становлять зміст ХК ПРИВИД.

Застосовуючи семантико-когнітивний аналіз мовних і мовленнєвих структур у вигляді такого алгоритму - процедури поетапної ідентифікації ХК: шляхом змістової компресії контекстів, де міститься інформація про привидів [Мур- зин] визначено їхні тематичні лінії; далі виявлено ключові елементи (далі - КЕ), серед яких визначено мовний засіб - тематичне слово як можливе потенційне найменування тематичної домінанти (далі - НТД) (або поєднаний із ним семантичними або асоціативними зв'язками), яке $є$ підставою для найменування художнього концепту (далі - НХК) [Chetova : 70].

Отже, ХК ПРИВИД ідентифіковано через установлення семантичних зв'язків та/або на основі асоціативного співвідношення (рис. 2).

У результаті дослідження семантичного й асоціативного аспектів та їх комбінування ідентифіковано такі концептуальні ознаки ХК ПРИВИД: джерело появи, походження у творах,

\begin{tabular}{|c|c|c|c|c|}
\hline ОГИДА & ШТУчнІсть & СМЕРТНICTЬ & ДОБРО & LЖA \\
\hline ВЦДРАЗА & ПРИРОДНІТЬ & БЕЗСМЕРТЯ & 3ЛО & $\mathrm{COH}$ \\
\hline ЗАХОПЛЕННЯ & «Походж. у & «Буття» & «Відношення до & \multirow{3}{*}{$\begin{array}{c}\text { ЗАхист } \\
\text { «Природиі } \\
\text { потреби» }\end{array}$} \\
\hline «Естетичне & творах»» & & Добра / Зла» & \\
\hline сприйняття» & & ПРИВИД & $v$ & \\
\hline $\begin{array}{c}\text { «Духовна } \\
\text { досконалість» }\end{array}$ & $\begin{array}{l}\text { «Духовна не- } \\
\text { досконалість» }\end{array}$ & \begin{tabular}{c|c} 
& $\downarrow$ \\
«Реакція»
\end{tabular} & $\begin{array}{c}\text { «нтелектуальні } \\
\text { здібності» }\end{array}$ & $\begin{array}{l}\text { «Характерна } \\
\text { особливість» }\end{array}$ \\
\hline НАДПЙНІСТЬ & ЖОРСТОКІСТЬ & ЖAX & IHTEЛЕКТ & вПлив \\
\hline РОЗСУДЛИВІСТЬ & БЕЗДУШНІСТЬ & CTPAX & MOBA & ФІЗІОЛОГТЧНА \\
\hline СПРАВЕДЛИВІСТЬ & ЛИЩЕМПСТВО & ВОРОЖІСТЬ & ПАМ'ЯТЬ & АНОМАЛЬЯ \\
\hline ЩИРІСТЬ & ОБМАH & ПЕРЕЛЯК & МИСЛЕННЯ & BIK \\
\hline ЛЮБОВ & АГРЕСІЯ & подив & МУДРІСТЬ & ЗОВНШШНІСТЬ \\
\hline ПОВАГА & НЕНАВИСТЬ & ЦІКАВІСТЬ & СВІДОМТСТЬ & СТАТЬ \\
\hline BIPA & ПТРЕЗИРСТВО & СИМПАТЬЯ & пнтуӥщц & 3PICT \\
\hline पЕCHICTЬ & ЗРАДА & РОЗГУБЛЕНІСТЬ & ПАРАНОРМ. & CTATYC \\
\hline ДОПОМОГА & ГРУБІСТЬ & $\downarrow$ & зДІБНОСТІ & ПРОФЕСLЯ \\
\hline BIPA & 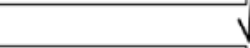 & «Фізична & (1) & ОДЯГ \\
\hline \multirow[t]{6}{*}{ ЖЕРТОВНICTЬ } & \multirow{2}{*}{$\begin{array}{c}\text { «Джерело } \\
\text { появи» }\end{array}$} & недосконалість» & «Стосунки» & АТРИБУТ \\
\hline & & ФІЗИЧНІ ВАДИ & ЗАЛЕЖНІСТЬ & \\
\hline & \multirow{2}{*}{$\begin{array}{l}\text { АВТ.ВИГАДКА } \\
\text { (у літературі) }\end{array}$} & ПОТВОРНІСТЬ & НЕЗАЛЕЖНІСТЬ & \\
\hline & & ПАТОЛОГІЯ & ДОМННУВАННЯ & \\
\hline & МІФОЛОГцЯ & ATABI3M & ДРУЖБА & \\
\hline & РЕЛІГЦЯ & ПСИХ.РОЗЛАДИ & ВОРОЖІСТЬ & \\
\hline
\end{tabular}

Рис. 3. Фрейм змістового шару ХК ПРИВИД в англомовних художніх творах про надприродне 
характерна особливість, ставлення до Добра / Зла, буття, духовна (не)досконалість, інтелектуальні здібності, естетичне сприйняття, фізична недосконалість, реакція, природні потреби та стосунки. Надалі було розглянуто структуру та наповнення ХК ПРИВИД, який розкрито так: через залучення методики концептуального аналізу, зокрема методики побудови фрейму, який демонструє системний зв'язок між концептуальними ознаками, реконструйовано загальні відомості про привидів у вигляді фрейму змістового шару ХК ПРИВИД (рис. 3).

Загалом, логічно впорядкована інформація про привиди розкриває базову ментальну візуалізацію явища, його конституентів, взаємодія яких представлена у вигляді фрейму, та репрезентує акумульовані знання про досліджуваний феномен: уявна (не)матеріалізована істота (людино-, твариноподібна або невизначеної подоби) як плід фантазії (автора або героя), 3 над/природними потребами та можливостями, певними інтелектуальними здібностями, духовними та фізичними (не)досконалостями, статусом та родом занять; істота, яка викликає певну реакцію (здебільшого страх та огиду) та слідує певній манері поведінки, яка стосується добра / зла та вирізняється 3-поміж інших деякими характерними особливостями (прозорість, ланцюги).

Як бачимо, аналіз лінгвокогнітивної реалізації явища привид у художніх творах сприяє розкриттю всієї палітри його ознак порівняно
3 наведеними в тлумачних словниках та словниках синонімів, що свідчить про неповне, обмежене їх представлення в лексикографічних джерелах та довідковій літературі.

Крім того, у процесі аналізу виявлено, що певні характерні ознаки привидів у письменників збігаються, як-от: to shake chains, to fade into mist, wicked face, shadowy hands, pale and transparent i т.д., але наявна і низка таких, що $є$ індивідуально-авторськими: a ghost that drank blood, phantom of alive person [Saruman] (Толкін), separation of spirit from matter the soul separated from the alive person (Вайлд), ghost teacher, the Inferius (a corpse that has been reanimated by a dark wizard's spells) (Роулінг) і т.п.

3 розвитком суспільства еволюціонували й уявлення письменників (а разом із ними і читачів) про привидів. Так, у ранніх творах трапляється інформація про їх чин чи статус - примари лицарів і чаклунів (Толкін), які згодом дещо трансформувались у професії та посади - привиди лихварів (Діккенс) та викладачів (Роулінг).

Висновки. Таким чином, проведене дослідження сприяє розширенню відомостей про характерні риси привидів в англомовній лінгвокультурі.

Перспективним уважається дослідження образно-асоціативного шару досліджуваного художнього концепту на основі зазначених творів задля виявлення всієї гами варіантів інтерпретації примар в англомовній літературі про надприродне.

\section{ЛІТЕРАТУРА}

1. Араратян М. Г. О коммуникативности образной системы художественного текста. Иностранные языки. Зарубежная литература. 1984. Вып. 3, стр. 17-24.

2. Мурзин Л. Н., Штерн А. С. Текст и его восприятие. Свердловск : Издательство Уральского университета. 1991. $172 \mathrm{c}$.

3. Ніконова В. Г. Художні концепти в трагедіях Шекспіра: методика ідентифікації. Вісник Черкаського університету. Серія Філологічні науки. 2005. Вип. 78, стор. 21-32.

4. Chetova N. The Imaginary: from Genre through Text and Language to Conceptual Space (Based on J.R.R. Tolkien's Literary Works). Lege artis. Language yesterday, today, tomorrow. 2019. vol. IV (2), pp. 49-85.

\section{ДЖЕРЕЛА}

1. Академічний тлумачний словник української мови (АTCУM). URL: http://sum.in.ua/s/pryvyd (Дата звернення: 20.11.2021)

2. Clute J., Grant J. (1997) The Encyclopedia of Fantasy. London : Orbit, 1049 p.

3. Encyclopedia Britannica. URL: https://www.britannica.com/topic/ghost-spirit (Дата звернення: 20.11.2021)

4. Dictionary.com. URL: https://www.dictionary.com/browse/ghost (Дата звернення: 20.11.2021)

5. Lexico.com. URL: https://www.lexico.com/browse/ghost (Дата звернення: 20.11.2021)

6. Oxford Learners Dictionary. URL: https:// www.oxfordlearnersdictionaries.com/definition/english/ ghost_1?q=ghost (Дата звернення: 20.11.2021)

7. Thesaurus.com. URL: https://www.thesaurus.com/browse/ghost (Дата звернення: 20.11.2021) 
8. Visual Thesaurus. URL: https://www.visual thesaurus.com/app/view/ghost (Дата звернення: 20.11.2021)

9. CC - Dickens Ch. A Christmas Carol. URL: https://www.planetebook.com/ free-ebooks/a-christmas-carol.pdf (Дата звернення: 20.11.2021).

10. CG - Wilde O. The Canterville Ghost. URL: https:/www.pf.jcu.cz/stru/kated ry/aj/doc/sukdolova/ual-wilde_ ghost.pdf (Дата звернення: 20.11.2021)

11. CS - Rowling J. K. Harry Potter and the Chamber of Secrets. URL: http://www.passuneb.com/elibrary/ebooks/ Harry\%20Potter\%20and\%20The\%20Chamber\%20of\%20Secrets.pdf (Дата звернення: 20.11.2021).

12. FR - Tolkien J. R. R. (2001) The Fellowship of the Ring. Boston. New York : Houghton Mifflin Co., 424 p.

13. HBP - Rowling J. K. Harry Potter and the Half-Blood Prince. URL: http://www.passuneb.com/elibrary/ebooks/ Harry\%20Potter\%20and\% 20The\%20Half-Blood\%20Prince.pdf (Дата звернення: 20.11.2021).

14. PDG - Wilde O. The Picture of Dorian Gray. URL: http://www.Planet publish.com/wp-content/uploads/2011/11/ The_Picture_of_Dorian_Gray_NT.pdf (Дата звернення: 20.11.2021)

15. TT - Tolkien J. R. R. (2001) The Two Towers. Boston - New York : Houghton Mifflin Co., 352 p.

\section{REFERENCES}

1. Araratyan M. G. (1984) O kommunikativnosti obraznoy sistemy khudozhestvennogo teksta [About the communicative aspects of the image system of the literary text]. Inostrannye yazyki. Zarubezhnaya literatura [Foreign Languages. Foreign Literature], vol. 3, pp. 17-24.

2. Murzin L. N., Shtern A. S. (1991) Tekst i ego vospriyatie [Text and its Perception]. Sverdlovsk: Izdatel'stvo Ural'skogo universiteta. 172 p. (In Russian)

3. Nikonova V. Gh. (2005) Khudozhni koncepty v traghedijakh Shekspira: metodyka identyfikaciji [Literary concepts in Shakespeare's tragedies: methodology of identification]. Visnyk Cherkasjkogho universytetu. Serija Filologhichni nauky [Cherkasy University Bulletin. Philological Sciences], vol. 78, pp. 21-32. (In Ukrainian)

4. Chetova N. (2019) The Imaginary: from Genre through Text and Language to Conceptual Space (Based on J.R.R. Tolkien's Literary Works). Lege artis. Language yesterday, today, tomorrow, vol. IV (2), pp. 49-85.

\section{SOURCES}

1. Akademichnyj tlumachnyj slovnyk ukrajinsjkoji movy (ATSUM). Retrieved from: http://sum.in.ua/s/pryvyd (In Ukrainian) (accessed: 20.11.2021)

2. Clute J., Grant J. (1997) The Encyclopedia of Fantasy. London : Orbit, 1049 p.

3. Encyclopedia Britannica. URL: https://www.britannica.com/topic/ghost-spirit (accessed: 20.11.2021)

4. Dictionary.com. URL: https://www.dictionary.com/browse/ghost (accessed: 20.11.2021)

5. Lexico.com. URL: https://www.lexico.com/browse/ghost (accessed: 20.11.2021)

6. Oxford Learners Dictionary. URL: https://www.oxfordlearners dictionaries.com/definition/english/ ghost_1?q=ghost (accessed: 20.11.2021)

7. Thesaurus.com. URL: https://www.thesaurus.com/browse/ghost (accessed: 20.11.2021)

8. Visual Thesaurus. URL: https://www.visualthesaurus.com/app/view/ghost (accessed: 20.11.2021)

9. CC - Dickens Ch. A Christmas Carol. URL: https://www. planetebook.com/free-ebooks/a-christmas-carol.pdf (accessed: 20.11.2021).

10. CG - Wilde O. The Canterville Ghost. URL: https://www.pf.jcu.cz/ stru/kated ry/aj/doc/sukdolova/ual-wilde_ ghost.pdf (accessed: 20.11.2021)

11. CS - Rowling J. K. Harry Potter and the Chamber of Secrets. URL: http://www.passuneb.com/elibrary/ebooks/ Harry\%20Potter\%20and\% 20The\%20Chamber\%20of\%20Secrets.pdf (accessed: 20.11.2021).

12. FR - Tolkien J. R. R. (2001) The Fellowship of the Ring. Boston. - New York : Houghton Mifflin Co., 424 p.

13. HBP - Rowling J. K. Harry Potter and the Half-Blood Prince. URL: http://www.passuneb.com/elibrary/ebooks/ Harry\%20Potter\%20and\% 20The\%20Half-Blood\%20Prince.pdf (accessed: 20.11.2021).

14. PDG - Wilde O. The Picture of Dorian Gray. URL: http:// www.Planetpublish. com/wp-content/uploads/2011/11/

The_Picture_of_Dorian_Gray_NT.pdf (accessed: 20.11.2021)

15. TT - Tolkien J. R. R. (2001) The Two Towers. Boston - New York : Houghton Mifflin Co., 352 p. 


\author{
N. Y. CHETOVA \\ Candidate of Philological Sciences, Associate Professor, \\ Associate Professor at the Department of Foreign Languages, \\ "Lviv Polytechnic" National University, Lviv, Ukraine \\ E-mail:kern_nata@ukr.net \\ https://orcid.org/0000-0003-3075-1692
}

\title{
LINGUOCOGNITIVE REALIZATION OF GHOST IN THE ENGLISH LITERATURE ABOUT THE SUPERNATURAL (BASED ON GHOST STORY, GOTHIC NOVEL AND FANTASY GENRES)
}

The article reveals the research of ghosts in the English literature about the supernatural and presents the analysis of realization of their peculiarities at the lingual and cognitive levels in the English literary works of such genres as ghost story, gothic novel and fantasy. In the process of research the attention was focused on the analysis of the nominative aspect of verbalization of ghosts, namely lexico-semantic space, along with the structuring of the basic information got as a result of analysis of the contexts, where ghosts were mentioned, and presented as a frame of the notional layer of the literary concept GHOST. The methodology of the investigation presupposes the application of the complex approach which is based on the linguopoetic and conceptual analysis. The lingual aspects of variety of ghosts in the literary works of Ch. Dickens, O. Wilde, J.R.R. Tolkien and J.K. Rowling, where the category of the imaginary expressed by these ghosts is realized the best, and where it is the genre-forming feature, thus were analysed.

On the basis of system-functional and semantic analysis it became possible to differentiate and group words that verbalize the variety of ghosts in the analysed literary works. The logically structured information about these creatures reveals the basic mental visualization of the phenomenon, its components, the interaction of which is presented in the form of a frame, and demonstrates the knowledge about the ghosts accumulated in the English ghost story, gothic novel and fantasy.

The present investigation shows common features of the ghost as one of the brightest examples of realization of the imaginary category in literature and reveals its supernatural manifestation in the English ghost story, gothic novel and fantasy.

Key words: ghost, ghost story, fantasy, gothic novel, literary concept, notional layer, frame. 